Check for updates

Cite this: RSC Adv., 2019, 9, 8557

\section{Photocatalytic dye degradation and biological activities of the $\mathrm{Fe}_{2} \mathrm{O}_{3} / \mathrm{Cu}_{2} \mathrm{O}$ nanocomposite $\uparrow$}

\author{
Mavinakere Ramesh Abhilash, (D) *a Gangadhar Akshatha ${ }^{\text {ab }}$ \\ and Shivanna Srikantaswamy ${ }^{\text {ab }}$
}

The present study reports the synthesis of the $\mathrm{Fe}_{2} \mathrm{O}_{3} / \mathrm{Cu}_{2} \mathrm{O}$ nanocomposite via a facile hydrothermal route. The products were characterized using X-ray diffractometry (XRD), Fourier-transform infrared spectroscopy (FTIR), dynamic light scattering (DLS), high-resolution transmission electron microscopy (HR-TEM), energy dispersive spectroscopy (EDS) and Brunauer-Emmett-Teller (BET) techniques. The composition, morphology and structural features of the nanoparticles were found to be size-dependent due to the temperature response in the particular time log during hydrothermal synthesis. HR-TEM confirmed the formation of hexagonal rod-shaped bare $\mathrm{Cu}_{2} \mathrm{O}$, rhombohedral-shaped $\mathrm{Fe}_{2} \mathrm{O}_{3}$ and composite assembly. Rhodamine-B (RB) and Janus green (JG) were chosen as model dyes for the degradation studies. Photocatalytic degradation of the dyes was deliberated by altering the catalyst and dye concentrations. The results showed that the Rhodamine-B (RB) and Janus green (JG) dyes were degraded within a short time span. The synthesized materials were found to be highly stable in the visible light-driven degradation of the dyes; showed antibacterial activity against E. coli, P. aeruginosa, Staph. aureus and B. subtilis; and exhibited less toxicity against the Musmusculus skin melanoma cells (B16-F10). The fusion of these advantages paves the way for further applications in energy conversion, biological applications as well as in environmental remediation.
Received 3rd December 2018 Accepted 28th February 2019

DOI: 10.1039/c8ra09929d

rsc.li/rsc-advances constitutes nearly $46 \%$ of the astral band. ${ }^{14}$ In recent years, the investigation of semiconductors for harvesting energy in the visible spectrum has led to the progression of the invention of non-titania-based semiconducting photocatalysts for dye degradation. ${ }^{15,16}$ In addition, the plasmon-resonance of fine metal oxide nanoparticles (MNP's) also enhances the photocatalytic process by absorbing incident photons much more effectively. $\mathrm{Cu}_{2} \mathrm{O}$ has been used as a prolific p-type photocatalyst with a through band gap in the visible range of 2.0$2.2 \mathrm{eV}^{17-19}$ However, $\mathrm{Cu}_{2} \mathrm{O}$ suffers from photo-wavering and photo-corrosion, which can over time cause deactivation in solar irradiation. ${ }^{20}$ Iron oxides $\left(\mathrm{Fe}_{2} \mathrm{O}_{3}\right)$, on the other hand, are an extremely constant n-type semiconductor under standard ambient conditions. ${ }^{21}$ The valence band-edge of $\mathrm{Fe}_{2} \mathrm{O}_{3}$ is an outstanding catalyst for the photo-squalor of unrefined pollutants and is not only abundant in nature but also massproducible. ${ }^{22}$ However, photocatalytic activity in $\mathrm{Fe}_{2} \mathrm{O}_{3}$ is often overwhelmed by its hole diffusion length (approximately, 10 $\mathrm{nm}$ ) and an extremely short electron-hole recombination time. ${ }^{23-25}$ Most studies focus on the antibacterial activity of metal nanoparticles and its composites, including those that are against resistant strains of microorganisms. However, there is no exact mechanism for the antimicrobial action of metal oxide nanoparticles. ${ }^{26}$ The anti-microbial activity of metal oxide nanoparticles was enhanced with increasing surface area and volume of the nanoparticles and decreasing particle size. ${ }^{27}$

\footnotetext{
${ }^{a}$ Department of Studies in Environmental Science, University of Mysore, Manasagangotri, Mysore 570006, India

${ }^{b}$ Centre for Materials Science and Technology, Vijnana Bhavan, University of Mysore, Manasagangotri, Mysore 570006, India.E-mail: abilashmrenvi@gmail.com

$\dagger$ Electronic supplementary information (ESI) available. See DOI: 10.1039/c8ra09929d
} 
Inimitable properties and the assessment of interactions between nanomaterials and the biological system are essential. ${ }^{28}$ In recent years, the cell line toxicity of human cell lines using several synthesized metal oxide is a more fascinating topic in understanding the relationship between nanoparticlecell interactions. ${ }^{\mathbf{2 9 , 3 0}}$ The size, shape, and morphology of nanoparticles, play a vital role in mammalian cell culture medium, and the nanoparticle are much more toxic than the hydrothermally synthesized nanocomposite semiconductor. ${ }^{31,32}$ In this experiment, we focus on exploiting and utilizing some multi-tasking facile materials with high photocatalytic activity and biological applications. To evade these drawbacks, in an attempt to tackle the above issues, we have developed a costeffective method for the synthesis of non-toxic $\mathrm{Fe}_{2} \mathrm{O}_{3}$ impurities on the $\mathrm{Cu}_{2} \mathrm{O}$ nanocomposite for various applications (Fig. 1 and 14). $\mathrm{Fe}_{2} \mathrm{O}_{3}$ burdened onto $\mathrm{Cu}_{2} \mathrm{O}$ and the nanocomposite was prepared by a facile method. The $(\mathrm{p}-\mathrm{n})$ hetero-junction nanocomposite was used for the effective degradation of organic pollutants; including Rhodamine-B (RB) and Janus green (JG), bacterial degradation and some additional biological screening applications.

\section{Experimental}

\subsection{Hydrothermal preparation of $\mathrm{Fe}_{2} \mathrm{O}_{3}$}

The hydrothermal technique has been found to be one of the best techniques to prepare $\mathrm{Fe}_{2} \mathrm{O}_{3}$ nanoparticles of the desired size with homogeneity in composition and an extreme degree of crystalline particles. The primary nanoparticles were synthesized by taking advantage of a hydrothermally enabled reaction between $\mathrm{FeCl}_{3}$ and $\mathrm{NaOH}$. Ammonia (Aldrich, India), $10.14 \mathrm{~g}$ $(37.5 \mathrm{~mol})$ of $\mathrm{FeCl}_{3} \cdot 6 \mathrm{H}_{2} \mathrm{O}$ and $7.45 \mathrm{~g}(37.5 \mathrm{mmol})$ of $\mathrm{FeCl}_{2} \cdot 4 \mathrm{H}_{2} \mathrm{O}$ were dissolved into $25 \mathrm{ml}$ of distilled water. $25 \mathrm{ml}$ of $25 \%$ ammonia was added to the salt solution under stirring at $700 \mathrm{rpm}$ for $2 \mathrm{~min}$. Next, $15 \mathrm{ml}$ of the mixture was put into a Teflon-lined stainless steel Morey autoclave. The autoclave was heated to $160{ }^{\circ} \mathrm{C}$ in an oven and maintained with a 12 hour reaction time. The effects of the reaction temperature on the

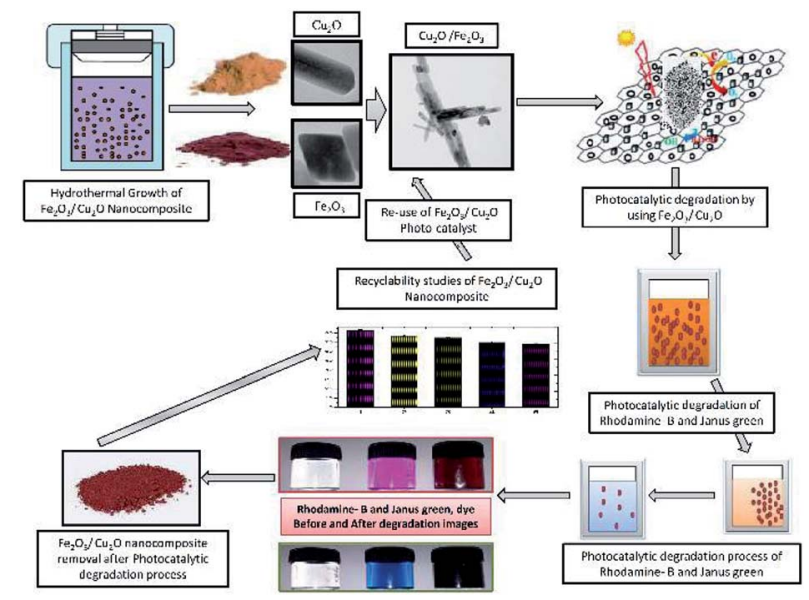

Fig. 1 Symmetric representation of the hydrothermal growth of $\mathrm{Fe}_{2} \mathrm{O}_{3} / \mathrm{Cu}_{2} \mathrm{O}$ nanocomposites; the photocatalytic activity of dye degradation and recyclability. product were investigated. Temperature plays a crucial role in the formation of a well-defined spherical product. The autoclave containing these chemicals was naturally cooled to room temperature, and the precipitates were then washed with distilled water and isolated under a magnet. The final products were dried at $60{ }^{\circ} \mathrm{C}$ and characterized. In the hydrothermal process, the following reaction takes place.

$$
\begin{array}{rl}
2 \mathrm{FeCl}_{3} \cdot 6 \mathrm{H}_{2} \mathrm{O}+2 & 2 \mathrm{FeCl}_{2} \cdot 4 \mathrm{H}_{2} \mathrm{O}+10 \mathrm{NH}_{4} \mathrm{OH} \\
& \rightarrow 2 \mathrm{Fe}_{2} \mathrm{O}_{3}+10 \mathrm{NH}_{4} \mathrm{Cl}+14 \mathrm{H}_{2} \mathrm{O}+\mathrm{H}_{2} \uparrow
\end{array}
$$

\subsection{Hydrothermal preparation of $\mathrm{Cu}_{2} \mathrm{O}$}

$\mathrm{Cu}_{2} \mathrm{O}$ nanocomposites were synthesized by using the reaction between copper sulfate and sodium hydroxide. $1.5 \mathrm{~g}$ of $\mathrm{CuSO}_{4}$ $\cdot 5 \mathrm{H}_{2} \mathrm{O}$ was first added into $80 \mathrm{ml}$ of distilled water under mechanical stirring at $60{ }^{\circ} \mathrm{C}$ for $30 \mathrm{~min}$, followed by the addition of $10 \mathrm{ml}$ of $\mathrm{NaOH}$ aqueous solution ( $1 \mathrm{M}$ ) into the solution. After 1 minute, a pinch of anhydrous glucose $(0.3 \mathrm{M})$ was quickly added and was mixed by mechanical stirring for about 30 minutes. The final solution was transferred into a Teflon-lined autoclave and hydrothermally treated at $80{ }^{\circ} \mathrm{C}$ for 5 hours. The resulting precipitate was collected, washed with distilled water followed by ethanol and vacuum dried at $60{ }^{\circ} \mathrm{C}$ for 6 hours.

$$
2 \mathrm{CuSO}_{4} \cdot 5 \mathrm{H}_{2} \mathrm{O}+2 \mathrm{NaOH} \rightarrow \mathrm{Cu}_{2} \mathrm{O}+2 \mathrm{NaSO}_{4}+6 \mathrm{H}_{2} \mathrm{O}
$$

\subsection{Preparation of $\mathrm{Fe}_{2} \mathrm{O}_{3} / \mathrm{Cu}_{2} \mathrm{O}$}

Nanocatalysts such as $\mathrm{Fe}_{2} \mathrm{O}_{3}$ and $\mathrm{Cu}_{2} \mathrm{O}$ synthesized from the above method were used to synthesize $\mathrm{Fe}_{2} \mathrm{O}_{3} / \mathrm{Cu}_{2} \mathrm{O}$ nanocomposites by a simple ultra-sonication method, in which the calculated 1:1 molar ratio of $\mathrm{Fe}_{2} \mathrm{O}_{3}: \mathrm{Cu}_{2} \mathrm{O}$ nanoparticles was sonicated in $50 \mathrm{ml}$ of $\mathrm{CHCl}_{3}$ solution for 20 minutes. During sonication, the nanoparticles were dispersed uniformly into a composite structure. The sonicated solution was filtered as wet solids, which were dried at $80^{\circ} \mathrm{C}$ for 5 hours.

\subsection{Photocatalytic experiments of the removal of dyes}

The photocatalytic behaviour of the synthesized nanomaterials was evaluated by the removal of Rhodamine-B (RB) and Janus green (JG) dyes $(200 \mathrm{ml}$ of aqueous solution of dyes $(1 \times$ $\left.10^{-5} \mathrm{~mol} \mathrm{l}^{-1}\right)$ ) under UV light radiation. The light source used was a $150 \mathrm{~W}$ Xe (Xenon) lamp, and the distance between the UV source and the photo-reaction vessel was $10 \mathrm{~cm}$. Prior to irradiation, the suspensions were magnetically stirred in the dark for $30 \mathrm{~min}$. Then, the photoreaction vessel was exposed to UV irradiation under standard ambient conditions. The selected dyes were used in conjunction with $10 \mathrm{mg}$ of catalyst nanoparticles in the photo-removal experiment. At regular time intervals, $3 \mathrm{ml}$ of the suspension was taken for centrifugation to separate the photocatalyst and for further evaluation using a UV-Vis absorption spectrometer. The photo-removal efficiency 
percentage was calculated from the equation given below. Afterward, recycling experiments were carried out for five repeated cycles to inspect the permanence of the photocatalytic $\mathrm{Fe}_{2} \mathrm{O}_{3} / \mathrm{Cu}_{2} \mathrm{O}$ nanocomposite. The composite catalyst was centrifuged, washed with ethanol and deionised water, and was dried before reuse for the next trial. The photo-removal efficiency percentage was calculated from the equation given below;

$$
\% \text { Photo-removal efficiency }=C_{0}-C / C_{0} \times 100
$$

where $C_{0}$ is the initial concentration of dye and $C$ is the concentration of dye after photo-irradiation (final).

\subsection{Determination of antibacterial activity and live and dead cell analysis}

The $\mathrm{Fe}_{2} \mathrm{O}_{3}, \mathrm{Cu}_{2} \mathrm{O}$ and the $\mathrm{Fe}_{2} \mathrm{O}_{3} / \mathrm{Cu}_{2} \mathrm{O}$ nanocomposite underwent bacterial screening along with the control by a disc diffusion method, ${ }^{33-35}$ against Gram-positive Bacillus subtilis, (MTCC 121) and Staphylococcus aureus (MTCC 7443) and Gramnegative Escherichia coli, (MTCC 7410) and Pseudomonas aeruginosa sp., (MTCC 733) bacteria. Hydrothermally synthesized $\mathrm{Fe}_{2} \mathrm{O}_{3}, \mathrm{Cu}_{2} \mathrm{O}$ and $\mathrm{Fe}_{2} \mathrm{O}_{3} / \mathrm{Cu}_{2} \mathrm{O}$ and the control were prepared in sterile distilled water (stock solution) over a range of different concentrations in $100 \mathrm{mg} \mathrm{ml}^{-1}$. The analysis was performed to distinguish dead and viable bacterial cells upon treatment with $\mathrm{Fe}_{2} \mathrm{O}_{3}, \mathrm{Cu}_{2} \mathrm{O}$ and $\mathrm{Fe}_{2} \mathrm{O}_{3} / \mathrm{Cu}_{2} \mathrm{O}$ NPs according to earlier reports, ${ }^{36}$ with minor modifications.

\subsection{Cell culture and treatment}

Musmelanoma cells (B16-F10) were seeded in tissue culture flasks and full-grown in Dulbecco's modified Eagle's medium (DMEM; Thermo Fisher, USA Gibco), balanced with 5\% fetal bovine serum (FBS, Thermo Fisher; Gibco) and 1\% penicillin/ streptomycin blend (Santa Cruz Biotechnology, USA). A detailed experiment procedure was clearly provided in S2 in ESI. $\dagger$

\subsection{Statistical analysis}

Systematic data replicates (three) were analyzed for every attempt and for every analysis of discrepancy (ANOVA) using SPSS-Inc. 16.0. Trivial effects of the treatments were resolved by $F$ values $(p \leq 0.05)$.

\section{Results and discussions}

\subsection{Characterization results of the synthesized $\mathrm{Fe}_{2} \mathrm{O}_{3} / \mathrm{Cu}_{2} \mathrm{O}$ nanocomposite}

The XRD spectrum of the $\mathrm{Fe}_{2} \mathrm{O}_{3} / \mathrm{Cu}_{2} \mathrm{O}$ photocatalyst with JCPDS data for $\mathrm{Cu}_{2} \mathrm{O}$ and $\mathrm{Fe}_{2} \mathrm{O}_{3}$ are shown in (Fig. 2). The prominent diffraction peaks at the angle $2 \theta=29.55,36.41,42.29,52.4$, 61.34 and $73.53^{\circ}$ respectively correspond to the (110), (111), (200), (211), (220) and (311) crystal planes of the hexagonal rodshaped $\mathrm{Cu}_{2} \mathrm{O}$ (05-0667-JCPDS). The (111) crystal plane of $\mathrm{Cu}_{2} \mathrm{O}$ in the composite is predicted to yield better performance in terms of photocatalytic activity. ${ }^{37}$ The two peaks found at $2 \theta=$

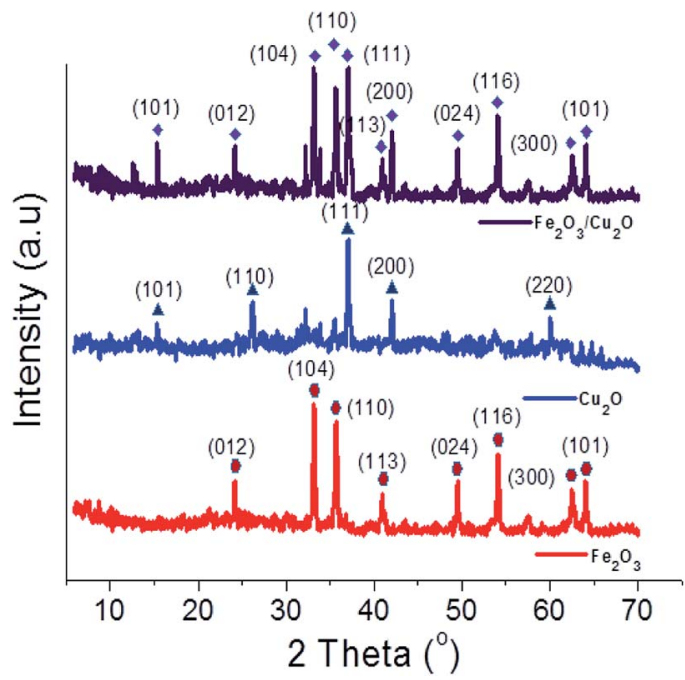

Fig. 2 X-ray diffraction profile of $\mathrm{Fe}_{2} \mathrm{O}_{3}, \mathrm{Cu}_{2} \mathrm{O}$ and $\mathrm{Fe}_{2} \mathrm{O}_{3} / \mathrm{Cu}_{2} \mathrm{O}$.

33.15 and 35.61 correspond to the (104) and (110) planes of rhombohedral $\mathrm{Fe}_{2} \mathrm{O}_{3}$, respectively (33-0664-JCPDS). ${ }^{38}$ The crystalline phase of the nanocomposite $\mathrm{Fe}_{2} \mathrm{O}_{3} / \mathrm{Cu}_{2} \mathrm{O}$ photocatalyst suggests that the hexagonal rod-shaped $\mathrm{Cu}_{2} \mathrm{O}$ with rhombohedral-shaped $\mathrm{Fe}_{2} \mathrm{O}_{3}$ would be evenly distributed and agglomerated over the entire surface. However, the photocatalyst $\mathrm{Fe}_{2} \mathrm{O}_{3} / \mathrm{Cu}_{2} \mathrm{O}$ exhibited a different structure with a different crystalline phase. The HR-TEM results matched with the XRD patterns, confirming that the experimental processes were ample.

FT-IR spectrum of the $\mathrm{Cu}_{2} \mathrm{O}, \mathrm{Fe}_{2} \mathrm{O}_{3}$ and $\mathrm{Fe}_{2} \mathrm{O}_{3} / \mathrm{Cu}_{2} \mathrm{O}$ photocatalysts are shown in (Fig. 3). The nanocatalyst with $\mathrm{Cu}_{2} \mathrm{O}$ and $\mathrm{Fe}_{2} \mathrm{O}_{3}$ are respectively associated with the $\mathrm{O}-\mathrm{H}$ bond stretching and bending vibration modes. ${ }^{39}$ The characteristic broad absorption peak adjusted from $700 \mathrm{~cm}^{-1}$ to $400 \mathrm{~cm}^{-1}$ as assigned to the fingerprint of the $\mathrm{Fe}_{2} \mathrm{O}_{3} / \mathrm{Cu}_{2} \mathrm{O}$ is $701 \mathrm{~cm}^{-1}$ in the $\mathrm{Cu}_{2} \mathrm{O}$ nanocomposite, allocated to the infrared active mode of $\mathrm{Cu}_{2} \mathrm{O}^{40}$ and the vigorous mode of $\mathrm{Cu}_{2} \mathrm{O} .{ }^{41}$ For bare $\mathrm{Fe}_{2} \mathrm{O}_{3}$, the absorption peaks at $572 \mathrm{~cm}^{-1}$ and $454 \mathrm{~cm}^{-1}$ correspond to the photocatalysis reaction of $\mathrm{Fe}^{3+}$. FT-IR spectra of $\mathrm{Cu}_{2} \mathrm{O}, \mathrm{Fe}_{2} \mathrm{O}_{3}$,

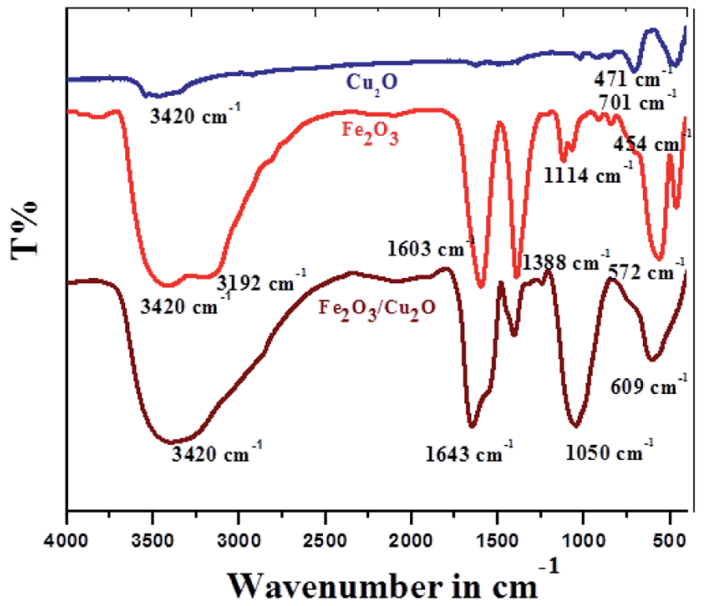

Fig. 3 FT-IR spectrum of different $\mathrm{Cu}_{2} \mathrm{O}, \mathrm{Fe}_{2} \mathrm{O}_{3}$ and $\mathrm{Fe}_{2} \mathrm{O}_{3} / \mathrm{Cu}_{2} \mathrm{O}$ photocatalysts. 
and the $\mathrm{Fe}_{2} \mathrm{O}_{3} / \mathrm{Cu}_{2} \mathrm{O}$ composite; $\mathrm{O}^{2-}$ bond stretching in the $\mathrm{FeO}_{6}$ octahedron; and $\mathrm{Fe}^{3+}$ and $\mathrm{O}^{2-}$ bond stretching in the $\mathrm{FeO}_{4}$ tetrahedron, respectively, are shown. ${ }^{42} \mathrm{Fe}_{2} \mathrm{O}_{3} / \mathrm{Cu}_{2} \mathrm{O}$ shows the presence of IR peaks caused by both photocatalysts, $\mathrm{Cu}_{2} \mathrm{O}$ and $\mathrm{Fe}_{2} \mathrm{O}_{3}$.

The nanoparticles synthesized by hydrothermal method resulting in the formation of nano/mesopore structure show excellent photocatalytic performance. ${ }^{\mathbf{4 3} 44}$ HR-TEM of the synthesized nanoparticles was shown in (Fig. 4); the highquality images of the hexagonal rod-shaped $\mathrm{Cu}_{2} \mathrm{O}$, rhombohedral-shaped $\mathrm{Fe}_{2} \mathrm{O}_{3}$ and $\mathrm{Fe}_{2} \mathrm{O}_{3} / \mathrm{Cu}_{2} \mathrm{O}$ composite nanoparticles with partial agglomeration are shown. Additionally, the nanocomposite results in the formation of mesopores between the particles, which were clearly confirmed by BET surface area and pore volume measurements. The sizes of both individual nanoparticles were between 30-60 nm, which are in accordance with the results of XRD. It was also observed that the $d$-spacing measurements of the twin domains were measured to be approximately $0.2 \AA$ to $0.4 \AA \mathrm{nm}$ and corresponded to the (111) and (220) planes of $\mathrm{Fe}_{2} \mathrm{O}_{3}$ and $\mathrm{Cu}_{2} \mathrm{O}$, respectively, and the SAED patterns confirmed the compact arrangement of the nanoparticles (Fig. S3 in ESI†). Energy dispersive spectroscopy (EDS) analysis confirmed the phase transparency of the $\mathrm{Fe}_{2} \mathrm{O}_{3}$, $\mathrm{Cu}_{2} \mathrm{O}$ and $\mathrm{Fe}_{2} \mathrm{O}_{3} / \mathrm{Cu}_{2} \mathrm{O}$ photocatalysts, as shown in (Fig. 5). The characteristic peaks of $\mathrm{Fe}, \mathrm{Cu}$, and $\mathrm{O}$ appear in the spectrum of $\mathrm{Fe}_{2} \mathrm{O}_{3} / \mathrm{Cu}_{2} \mathrm{O}$ and confirm its successive formation and purity (Fig. S2 in $\mathrm{ESI}_{\dagger}^{\dagger}$ ). The carbon peak appears due to the carbon tape used sample holder.

The particle size distribution was analyzed using a dynamic light scattering instrument. The $\mathrm{Fe}_{2} \mathrm{O}_{3} / \mathrm{Cu}_{2} \mathrm{O}$ particles were dispersed in a solvent. The distribution of particle sizes when immersed in the solvent ranged from 42-593 $\mathrm{nm}$, with approximately $266 \mathrm{~nm}$ being the mean particle size. Histogram of the DLS analysis for the particle size distribution of $\mathrm{Fe}_{2} \mathrm{O}_{3}$ / $\mathrm{Cu}_{2} \mathrm{O}$ composites is depicted in (Fig. S1 in ESI $\dagger$ ). Zeta potential measurements by DLS were considered as an authentic technique for evaluating the particle size and zeta potentials of nanoparticles in a suspension and also plays a crucial role

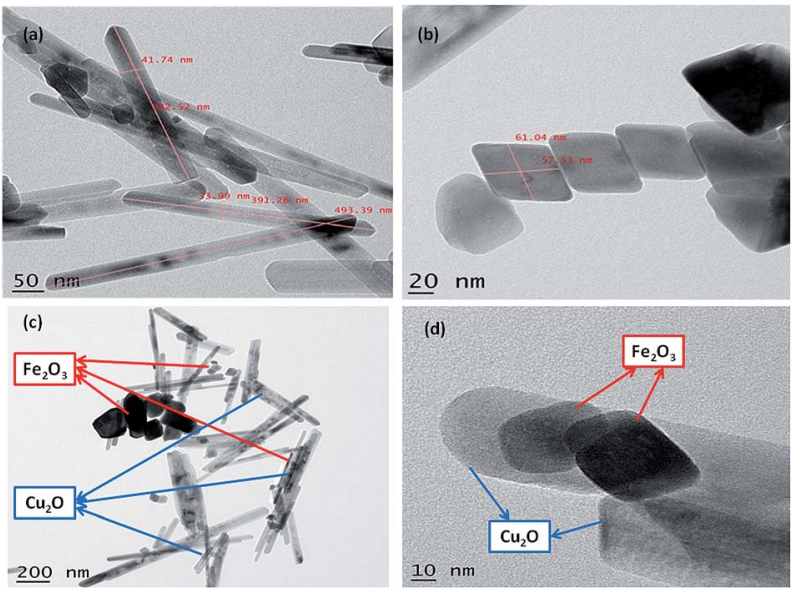

Fig. $4 \mathrm{HR}$-TEM of (a) $\mathrm{Cu}_{2} \mathrm{O}$ nanoparticles, (b) $\mathrm{Fe}_{2} \mathrm{O}_{3}$ nanoparticles, (c) hexagonal rod-shaped $\mathrm{Cu}_{2} \mathrm{O}$ and rhombohedral-shaped $\mathrm{Fe}_{2} \mathrm{O}_{3}$; (d) $\mathrm{Cu}_{2} \mathrm{O} / \mathrm{Fe}_{2} \mathrm{O}_{3}$ nanocomposite assembly, scale bar is in $\mathrm{nm}$.

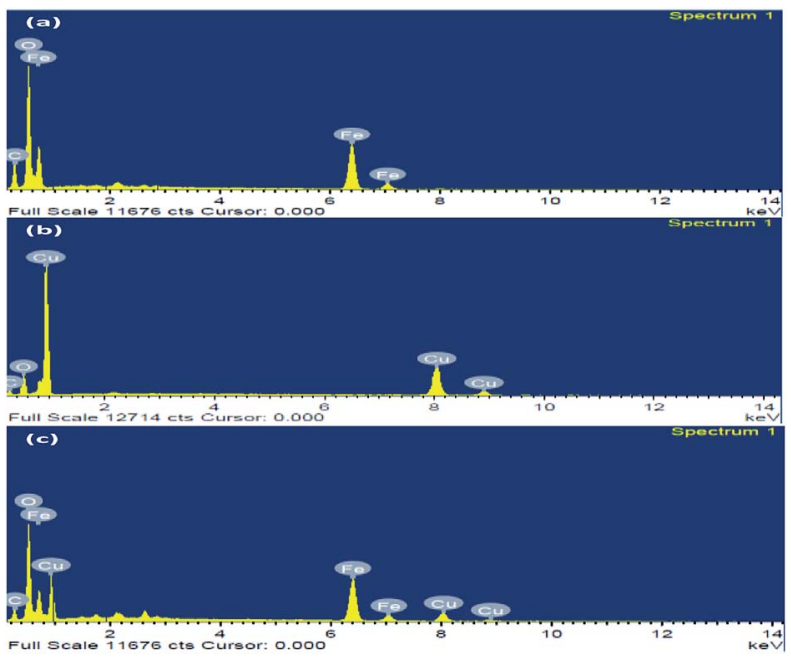

Fig. 5 The elemental composition in the EDS of (a) $\mathrm{Fe}_{2} \mathrm{O}_{3}$, (b) $\mathrm{Cu}_{2} \mathrm{O}$, and (c) $\mathrm{Fe}_{2} \mathrm{O}_{3} / \mathrm{Cu}_{2} \mathrm{O}$

during interaction with other biological systems as well as environmental degradation. The particles examined presently possessed zeta potentials of $-0.1 \mathrm{mV}$ for $\mathrm{Cu}_{2} \mathrm{O}, 13.9 \mathrm{mV}$ for $\mathrm{Fe}_{2} \mathrm{O}_{3}$, and $-46.2 \mathrm{mV}$ for the $\mathrm{Fe}_{2} \mathrm{O}_{3} / \mathrm{Cu}_{2} \mathrm{O}$ composite. Nanoparticles with a zeta potentials between -10 and $+10 \mathrm{mV}$ have a neutral charge, while if it is greater than $+30 \mathrm{mV}$ or less than $-30 \mathrm{mV}$, it is considered to be strongly cationic or anionic.

Surface area is an important parameter to determine the photocatalytic activity of the nanoparticles. A photocatalyst with a high surface area is likely to absorb more dye molecules and react faster (Table 1); the BET surface area as a function of the pore volume of the prepared samples undoubtedly demonstrates a similar type II curve. The BET surface area of $\mathrm{Fe}_{2} \mathrm{O}_{3}, \mathrm{Cu}_{2} \mathrm{O}$ and $\mathrm{Fe}_{2} \mathrm{O}_{3} / \mathrm{Cu}_{2} \mathrm{O}$ were found to be 5.676, 9.90, and $10.401 \mathrm{~m}^{2} \mathrm{~g}^{-1}$, respectively (Fig. 6). According to the hysteresis loop in the relative pressure region around $0.4-0.9$, the nitrogen adsorption/ desorption isotherms showed that the $\mathrm{Fe}_{2} \mathrm{O}_{3} / \mathrm{Cu}_{2} \mathrm{O}$ exhibited a similar type IV curve. In other words, the $\mathrm{Fe}_{2} \mathrm{O}_{3} / \mathrm{Cu}_{2} \mathrm{O}$ nanocomposite existed with a mesoporous structure. The surface area of the $\mathrm{Fe}_{2} \mathrm{O}_{3} / \mathrm{Cu}_{2} \mathrm{O}$ repressed a huge difference in the bare nanoporous $\mathrm{Fe}_{2} \mathrm{O}_{3}$ and $\mathrm{Cu}_{2} \mathrm{O}$. With an increase in the surface area and decrease in pore size, as well as the large total pore volume, the $\mathrm{Fe}_{2} \mathrm{O}_{3} / \mathrm{Cu}_{2} \mathrm{O}$ is expected to have a high photocatalytic activity.

The common Tauc approach was used to approximate the band gap energy $\left(E_{\mathrm{g}}\right)$ values. It was found that the band gap energy values of $\mathrm{Fe}_{2} \mathrm{O}_{3}, \mathrm{Cu}_{2} \mathrm{O}$ and the $\mathrm{Fe}_{2} \mathrm{O}_{3} / \mathrm{Cu}_{2} \mathrm{O}$ nanocomposite were respectively $1.96 \mathrm{eV}, 1.89 \mathrm{eV}$ and $1.85 \mathrm{eV}$. The surface charge on the metal oxides in aqueous solution becomes obvious: recognition to the progression of hydration,

Table 1 Surface parameters of $\mathrm{Fe}_{2} \mathrm{O}_{3}, \mathrm{Cu}_{2} \mathrm{O}$ and $\mathrm{Fe}_{2} \mathrm{O}_{3} / \mathrm{Cu}_{2} \mathrm{O}$

\begin{tabular}{lcl}
\hline Photocatalyst & $S_{\text {BET }}\left(\mathrm{m}^{2} \mathrm{~g}^{-1}\right)$ & $\begin{array}{l}\text { Pore volume } \\
\left(\mathrm{cm}^{3} \mathrm{~g}^{-1}\right)\end{array}$ \\
\hline $\mathrm{Fe}_{2} \mathrm{O}_{3}$ & 5.676 & 1.304 \\
$\mathrm{Cu}_{2} \mathrm{O}$ & 9.90 & 2.275 \\
$\mathrm{Fe}_{2} \mathrm{O}_{3} / \mathrm{Cu}_{2} \mathrm{O}$ & 10.401 & 2.389
\end{tabular}



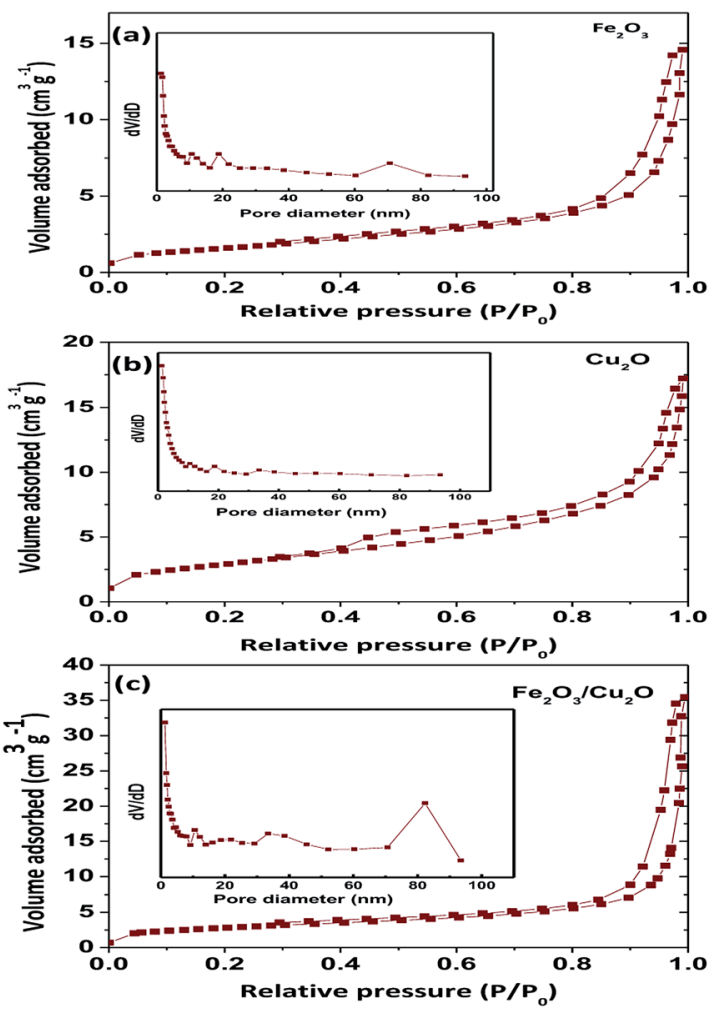

Fig. 6 BET, $\mathrm{N}_{2}$ adsorption isotherms of (a) $\mathrm{Fe}_{2} \mathrm{O}_{3}$, (b) $\mathrm{Cu}_{2} \mathrm{O}$, and (c) $\mathrm{Fe}_{2} \mathrm{O}_{3} / \mathrm{Cu}_{2} \mathrm{O}$.

protonation, and deprotonation of the surface groups. ${ }^{45} \mathrm{RB}$ is a cationic dye. ${ }^{46} \mathrm{JG}$ is basic dyes which, together with (RB), are scarcely absorbed on the $\mathrm{Fe}_{2} \mathrm{O}_{3} / \mathrm{Cu}_{2} \mathrm{O}$ surface due to its negative zeta potential. However, the deliberate zeta potential was found to be $-46.2 \mathrm{mV}$, suggesting the presence of a negative charge on the surface of the $\mathrm{Fe}_{2} \mathrm{O}_{3} / \mathrm{Cu}_{2} \mathrm{O}$ photocatalyst. ${ }^{47}$ The negative surface charge favours the adsorption of cationic as well as basic dyes due to the increased electrostatic force of attraction. The surface conductivity of the $\mathrm{Fe}_{2} \mathrm{O}_{3} / \mathrm{Cu}_{2} \mathrm{O}$ photocatalyst was found to be $0.229 \mathrm{mS} \mathrm{cm}^{-1}$.

The surface properties of $\mathrm{Fe}_{2} \mathrm{O}_{3}, \mathrm{Cu}_{2} \mathrm{O}$ were affected by changes in pH. The pzc (point of zero charge) values for $\mathrm{Fe}_{2} \mathrm{O}_{3}$ and $\mathrm{Fe}_{2} \mathrm{O}_{3}, \mathrm{Cu}_{2} \mathrm{O}$ were found to be 6.9 and 7.2 respectively. It was observed that $\mathrm{RB}$ and JG in an acidic environment can advantageously increase the electrostatic attraction between the protons from the catalysts, including the dyes, RB and JG. Thus, photo-removal activity is high. At low $\mathrm{pH}$ (below 5), the chances for agglomeration are high, thus reducing the active surface area available for dye adsorption and photon absorption. At an optimum $\mathrm{pH}$, the predominant iron site, namely $\mathrm{Fe}(\mathrm{OH})^{2+}$, not only forms $\mathrm{Fe}(\mathrm{II})$, the major catalytic species in the photoremoval reactions, but also produces additional ${ }^{-} \mathrm{OH}$ responsible for dye removal. When the $\mathrm{pH}$ value was greater than pzc, the surface of $\mathrm{Fe}_{2} \mathrm{O}_{3} / \mathrm{Cu}_{2} \mathrm{O}$ became negatively charged. Therefore, the negatively charged dye molecules were repelled by the catalyst surface, leading to a decrease in the effective photocatalytic activity. Highly alkaline conditions are favourable for the generation of a large number of less reactive high-valence composite iron species (Fig. 7).
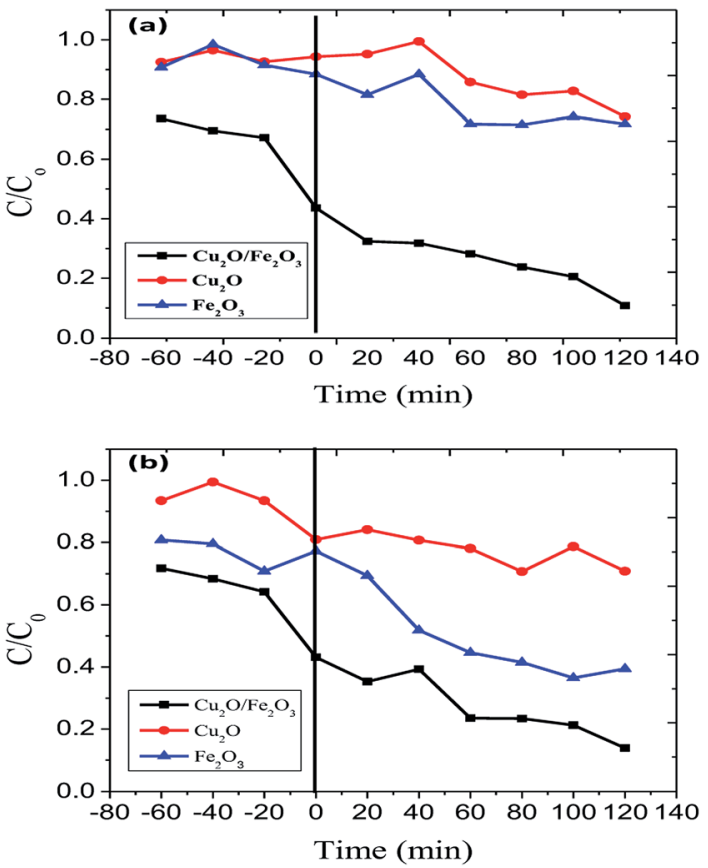

Fig. 7 Photo-removal of (a) Rhodamine- $\mathrm{B}$ (RB) and (b) Janus green (JG) using $\mathrm{Cu}_{2} \mathrm{O}, \mathrm{Fe}_{2} \mathrm{O}_{3}$ and the $\mathrm{Fe}_{2} \mathrm{O}_{3} / \mathrm{Cu}_{2} \mathrm{O}$ photocatalysts.

The Langmuir-Hinshelwood model was engaged to investigate the kinetics of $\mathrm{RB}$ and JG photo-removal. The photocatalytic experiments were carried out under optimal reaction conditions $\left[\mathrm{Fe}_{2} \mathrm{O}_{3}=0.75 \mathrm{~g} \mathrm{l}^{-1}\right.$, both $\mathrm{RB}$ and $\mathrm{JG}=9 \mathrm{mM}$ and $\mathrm{pH}$ 5]. Fig. 8 shows the logarithmic plot of RB and JG concentration as a function of irradiation time. The photocatalytic removal of
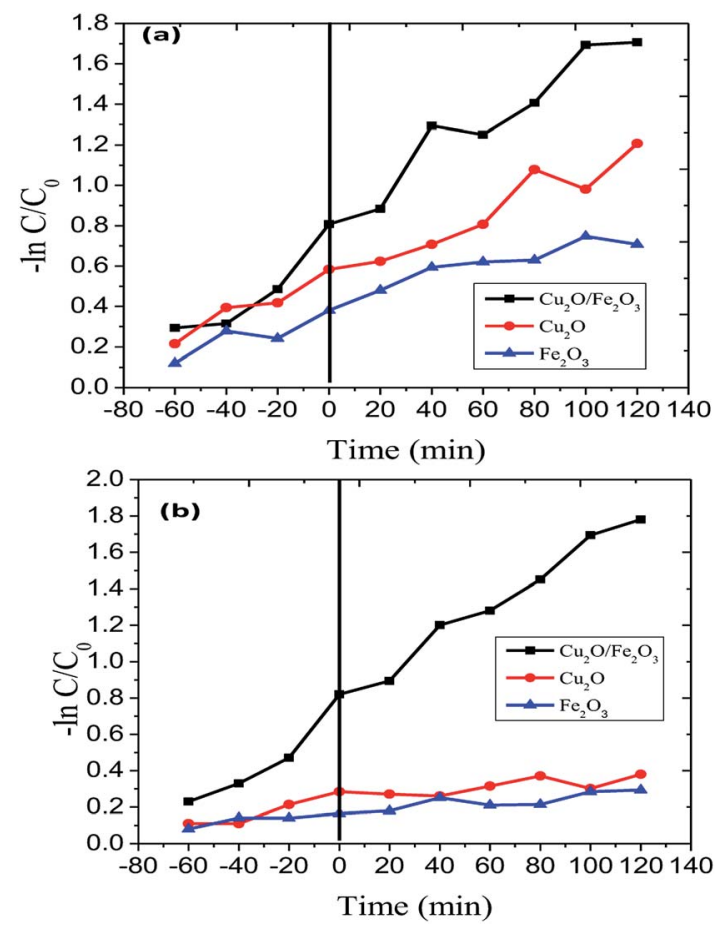

Fig. 8 Kinetics of (a) Rhodamine- $\mathrm{B}$ (RB) and (b) Janus green (JG) photo-removal using $\mathrm{Cu}_{2} \mathrm{O}, \mathrm{Fe}_{2} \mathrm{O}_{3}$ and the $\mathrm{Fe}_{2} \mathrm{O}_{3} / \mathrm{Cu}_{2} \mathrm{O}$ photocatalyst. 
$\mathrm{RB}$ and JG follows pseudo-first-order kinetics; the pragmatic rate constant for $\mathrm{Fe}_{2} \mathrm{O}_{3} / \mathrm{Cu}_{2} \mathrm{O}$ of $1.21 \times 10^{-2} \mathrm{~s}^{-1}$ is significantly higher than those of $\mathrm{Fe}_{2} \mathrm{O}_{3}\left(4.36 \times 10^{-3} \mathrm{~s}^{-1}\right)$ and $\mathrm{CuO}_{2}(6.45 \times$ $\left.10^{-3} \mathrm{~s}^{-1}\right)$. Hence, the activity of the $\mathrm{Fe}_{2} \mathrm{O}_{3}$ nano-porous material is about approximately 2.6 times higher than that of other demonstrated materials in a systematic manner. DRS was used to investigate the light-harvesting nature of the $\mathrm{Fe}_{2} \mathrm{O}_{3} / \mathrm{Cu}_{2} \mathrm{O}$ photocatalyst. Estimating the conduction-band minimum (CBM) and the valence-band maximum (VBM) is vital to understanding the mechanism of the photocatalytic degradation of the photocatalyst. To investigate the CBM and VBM of $\mathrm{Fe}_{2} \mathrm{O}_{3}, \mathrm{Cu}_{2} \mathrm{O}$, or $\mathrm{Fe}_{2} \mathrm{O}_{3} / \mathrm{Cu}_{2} \mathrm{O}$, the UV-DRS spectra were used to record the spectrum. As shown, the associated band gap values were calculated using the following eqn: ${ }^{48}$

$$
\alpha h \nu=A\left(h \nu-E_{\mathrm{g}}\right)^{n}
$$

The calculated band gaps of bare $\mathrm{Fe}_{2} \mathrm{O}_{3}$ and $\mathrm{Cu}_{2} \mathrm{O}$ were found to be 1.96 and $1.89 \mathrm{eV}$, (Fig. 9) respectively, which are consistent with similar results obtained from related work. ${ }^{49}$ The observed small red-shift in the band gap value $(1.85 \mathrm{eV})$ of the $\mathrm{Fe}_{2} \mathrm{O}_{3} / \mathrm{Cu}_{2} \mathrm{O}$ photocatalyst is possibly due to the formation of a $\mathrm{p}-\mathrm{n}$ heterojunction between the p-type $\mathrm{Cu}_{2} \mathrm{O}$ and the n-type $\mathrm{Fe}_{2} \mathrm{O}_{3} .{ }^{50}$

In the exploration of the photocatalytic dye removal activity, it was found that the $1.5 \%$ loading of $\mathrm{Fe}_{2} \mathrm{O}_{3}$ on $\mathrm{Cu}_{2} \mathrm{O}$ exhibits sophisticated performance compared to those of 0.8 and $2.4 \%$ loading. Fig. 7 displays the rate of the adsorption and photoremoval of Rhodamine- $\mathrm{B}$ and Janus green dyes for $\mathrm{Cu}_{2} \mathrm{O}, \mathrm{Fe}_{2} \mathrm{O}_{3}$ and $\mathrm{Fe}_{2} \mathrm{O}_{3} / \mathrm{Cu}_{2} \mathrm{O}$. Due to its negative surface charge, the optimized photocatalyst $\mathrm{Fe}_{2} \mathrm{O}_{3} / \mathrm{Cu}_{2} \mathrm{O}$ was found to have adsorbed the dyes under visible-light irradiation. The $\mathrm{Fe}_{2} \mathrm{O}_{3} / \mathrm{Cu}_{2} \mathrm{O}$ photocatalyst had effectively degraded the RB and JG dyes. It can be clearly seen that $1.5 \% \mathrm{Fe}_{2} \mathrm{O}_{3}$ loaded onto the $\mathrm{Cu}_{2} \mathrm{O}$ photocatalyst is much more efficient than bare $\mathrm{Cu}_{2} \mathrm{O}$ towards cationic as well as basic dyes like $\mathrm{RB}$ and JG removal. Compared to bare $\mathrm{Fe}_{2} \mathrm{O}_{3}$ or $\mathrm{Cu}_{2} \mathrm{O}, \mathrm{Fe}_{2} \mathrm{O}_{3} / \mathrm{Cu}_{2} \mathrm{O}$

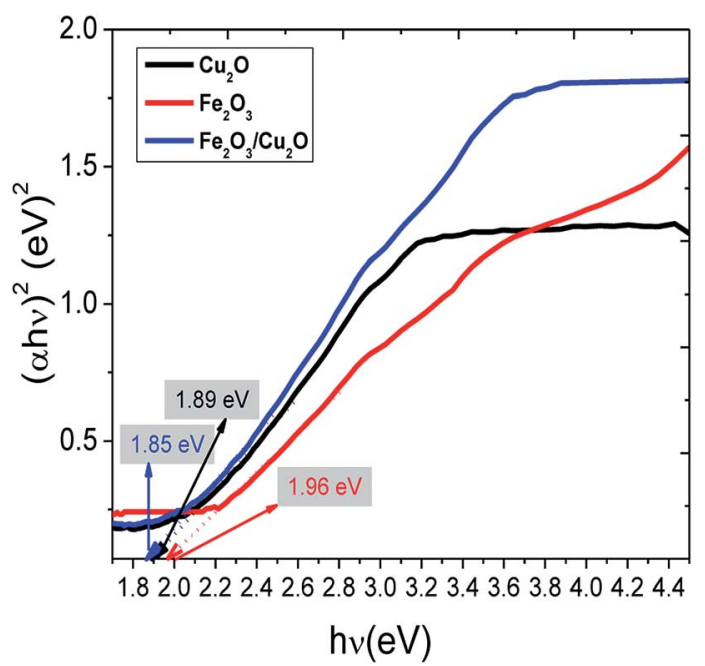

Fig. 9 The band gap calculation using the Tauc plot of pristine $\mathrm{Fe}_{2} \mathrm{O}_{3}$, $\mathrm{Cu}_{2} \mathrm{O}$ and the $\mathrm{Fe}_{2} \mathrm{O}_{3} / \mathrm{Cu}_{2} \mathrm{O}$ photocatalyst. was a much more effective photocatalyst that enhances the removal rate of Rhodamine-B and Janus green.

\subsection{Total organic carbon (TOC) and chemical oxygen demand (COD) studies of Rhodamine-B (RB-B) and Janus green (JG)}

This analysis is necessary because the disappearance of dye colour alone cannot be used as a measure to determine the complete mineralization of the dyes..$^{51-54}$ Noxious and longlasting reaction intermediates were formed during the photoremoval of the dyes. Simultaneously, it was essential to calculate the degree of degradation of Rhodamine-B (RB) and Janus green (JG) during photo-removal using the $\mathrm{Fe}_{2} \mathrm{O}_{3} / \mathrm{Cu}_{2} \mathrm{O}$ photocatalyst. After the degradation process, it was a necessity to measure the chemical oxygen demand (COD) and total organic carbon (TOC) to assess the purity of degraded dyes before the discharging process. Total organic carbon (TOC) analysis was performed in order to determine the extent of mineralization of Rhodamine-B (RB-B) and Janus green (JG) during the photocatalytic degradation process. The present work shows the significantly declining performance in the particular functioned period (Fig. 10). Furthermore, the photocatalytic degradation process can result in the formation of colourless dye intermediates resulting in the disappearance of colour, which may actually be more toxic than the dye itself. The present study revealed that the colour disappearance of the dye was faster than the degree of mineralization with maximum TOC removal (Table S3 in ESI $\dagger$ ). The rapid loss of colour might arise from the cleavage of the azo bond, while the high TOC value may be due to difficulty in converting the $\mathrm{N}$-atom of the dye into oxidized nitrogen compounds. This mechanism clearly explained that the dye molecules were converted to other intermediates and that the dye was systematically decolourized in $120 \mathrm{~min}$, which may lead to complete mineralization. Similarly, the reduction of
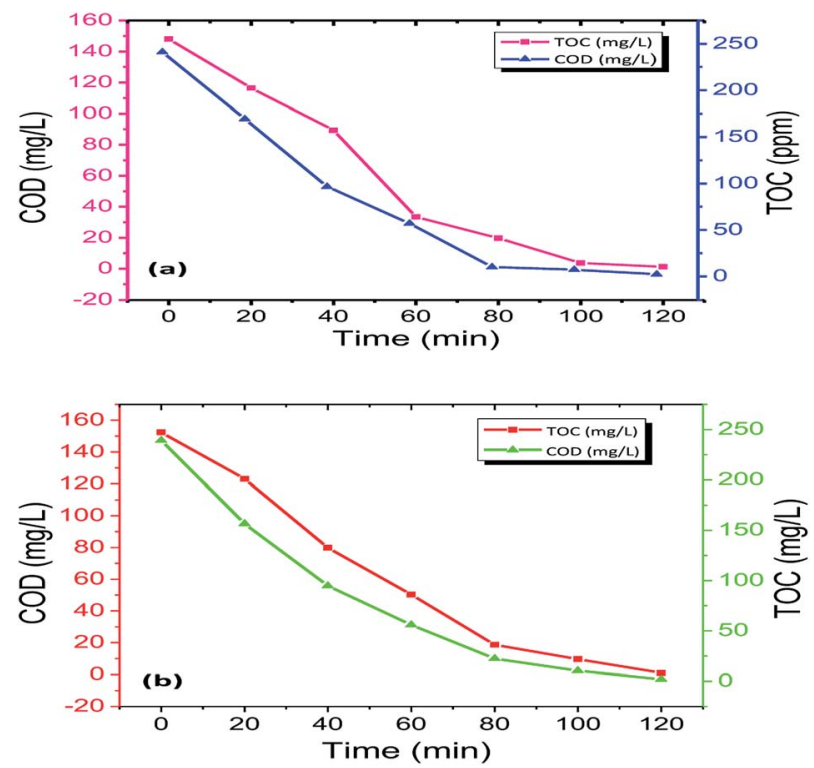

Fig. 10 TOC and COD measurements of (a) Rhodamine-B (RB-B) and (b) Janus green (JG) degradation by the $\mathrm{Fe}_{2} \mathrm{O}_{3} / \mathrm{Cu}_{2} \mathrm{O}$ photocatalyst. 
COD reflects the extent of removal or mineralization of an organic species (Table S4 in ESI $\dagger$ ), the percentage change in COD and TOC during photo-removal was measured under optimum reaction conditions [Rhodamine-B (RB) and Janus green (JG) concentration $9 \mathrm{mM}$, catalyst concentration $0.75 \mathrm{~g}$ $\mathrm{l}^{-1}, \mathrm{pH}=5$ and irradiation time of up to $\left.120 \mathrm{~min}\right]$. The solutions obtained after 120 min of photo-removal showed a significant decrease in COD and TOC concentration. It has been observed that Rhodamine-B (RB) and Janus green (JG) molecules were partially degraded to intermediates, and only a small fraction was subjected to complete mineralization; the COD showed a related emergent action similar to TOC.

\subsection{Photodegradation intermediates of Rhodamine-B (RB- B) and Janus green (JG)}

The intermediates and final products would help to figure out the details of the reaction process. Because of the spectral overlap between the original dye and its degradation intermediates. Temporal variations during the photooxidation of Rhodamine-B (RB) and Janus green (JG) were systematically executed by LC-MS. According to earlier reports, ${ }^{55-57}$ small molecules were mineralized to form $\mathrm{CO}_{2}$ and $\mathrm{H}_{2} \mathrm{O}$, which can be proven by the results of the TOC measurement. The two competitive processes occurred simultaneously during the photoreaction: $\mathrm{N}$-deethylation and destruction of dye chromophore structure, under visible light irradiation. Most of the $N$ deethylation processes were preceded by the formation of a nitrogen-centered radical, while the destruction of dye chromophore structures is preceded by the generation of a carboncentered radical. The photogenerated active species such as - OH could directly attack the central carbon of Rhodamine-B (RB) (Fig. S4 in ESI $\dagger$ ) and Janus green (JG) (Fig. S18 in ESI $\dagger$ ), for the degradation of the dye. These dynamic species work on any $\mathrm{N}$-deethylation intermediates to continue the deethylation process and turn the adsorption of Rhodamine-B (RB) and Janus green (JG) on the $\mathrm{Fe}_{2} \mathrm{O}_{3} / \mathrm{Cu}_{2} \mathrm{O}$ catalyst surface. Intermediates of the photocatalytic degradation of Rhodamine-B (RB) (Fig. 11) and (Fig. S5-S15 in ESI $\dagger$ ), using $\mathrm{Fe}_{2} \mathrm{O}_{3} / \mathrm{Cu}_{2} \mathrm{O}$ are benzoic acid, benzylidyneoxonium, $(E)$-4-amino-2-(prop-1-en-1-yl) phenol, 3-imino-3H-xanthen-6-amine, (Z)-3-(ethylimino)-3Hxanthen-6-amine, $\quad(E)$ - $N, N$-diethyl-3-(diethylammonium)-3Hxanthen-6-amine, 2-(6-amino-3-imino-3H-xanthen-9-yl)benzoic

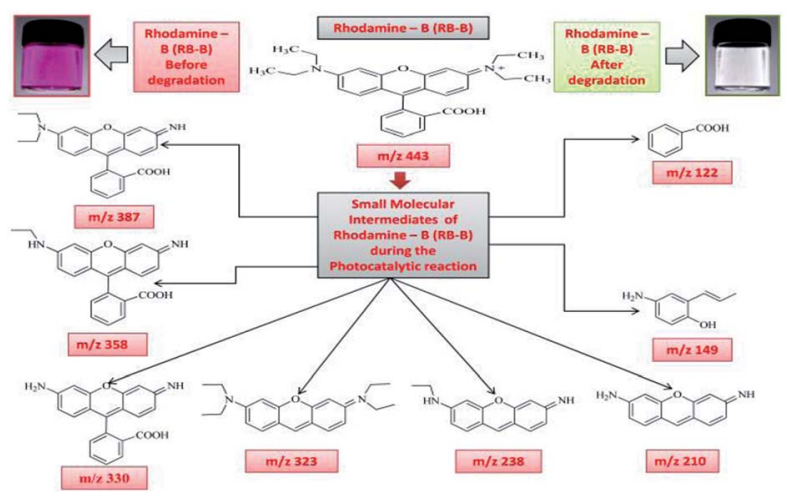

Fig. 11 Photodegradation intermediates of Rhodamine-B (RB-B).

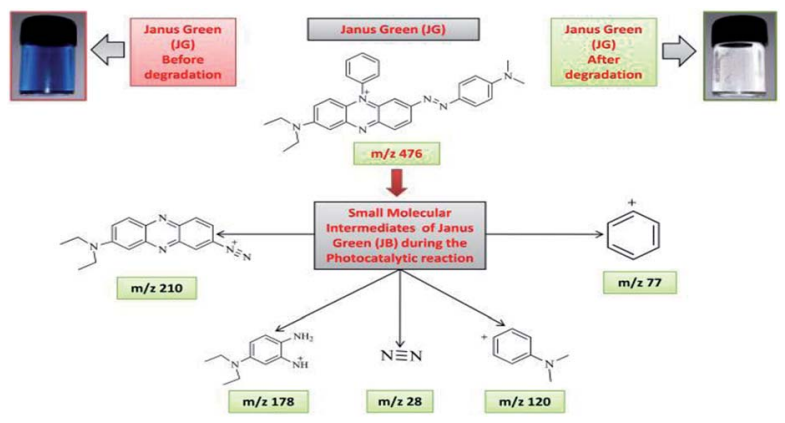

Fig. 12 Photo-degradation intermediates of Janus green (JG).

acid, 2-(6-(ethylamino)-3-imino-3H-xanthen-9-yl)benzoic acid and 2-(6-(diethylamino)-3-imino-3H-xanthen-9-yl) benzoic acid, as clearly demonstrated in (Table S1 in ESI $\uparrow$ ). In Fig. 12, S16 and S17 in ESI, $\dagger$ photocatalytic degradation of Janus green (JG) resulted in the evolution of nitrogen, which took prominence over deethylation, leading to the formation of dinitrogen, benzene-1-ylium, 4-(dimethylamino)benzene-1-ylium, $N_{4}, N_{4^{-}}$ diethylbenzene-1,2,4-triamine cation, 8(diethylamino) phenazine-2-diazonium intermediates (Table S2 in ESI $\dagger$ ). In the present context, the cleavage of the dye chromophores by $\mathrm{Fe}_{2} \mathrm{O}_{3} /$ $\mathrm{Cu}_{2} \mathrm{O}$ has been hypothesized.

To evaluate the stability and re-usability of the $\mathrm{Fe}_{2} \mathrm{O}_{3} / \mathrm{Cu}_{2} \mathrm{O}$ photo-catalyst, five additional cycles of dye RB and JG removal were performed with it. Fig. 13 shows the good recyclability of the $\mathrm{Fe}_{2} \mathrm{O}_{3} / \mathrm{Cu}_{2} \mathrm{O}$ photo-catalyst for five consecutive cycles. A slight decrease in activity for the fifth cycle of RB and JG may be due to the loss of catalyst due to its recyclability. This result
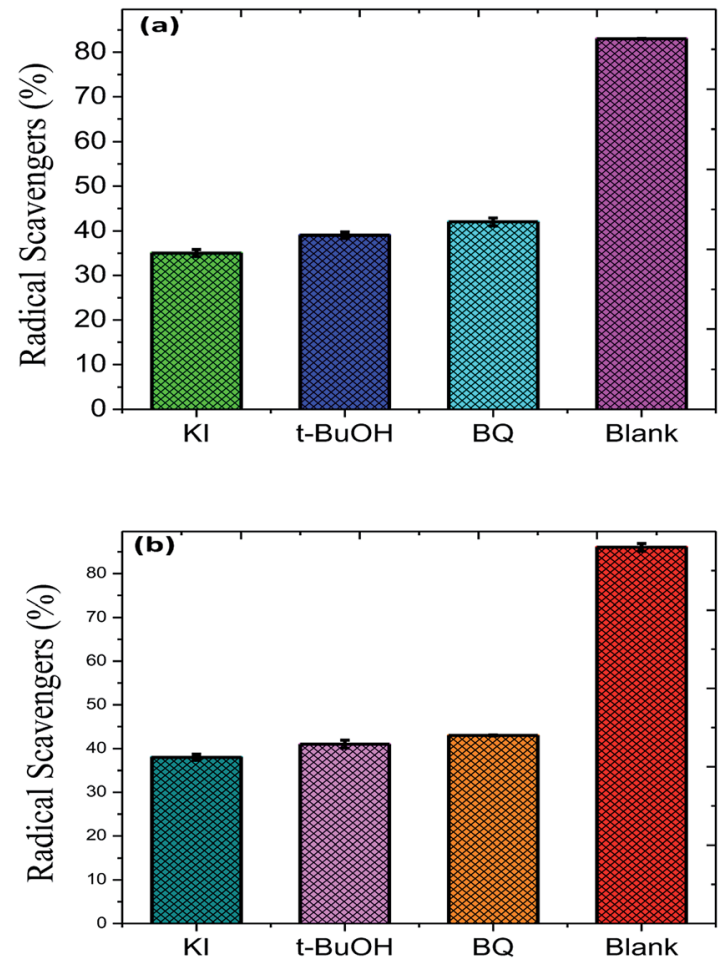

Fig. 13 Role of different radical scavengers on the photo-removal of (a) Rhodamine-B (RB) and (b) Janus green (JG). 
clearly indicates that both dyes degraded into carbon dioxide and water as the final products. The experiments were carried out under optimal reaction conditions ( $\mathrm{RB}$ and $\mathrm{JG}=9 \mathrm{mM}$, $\mathrm{Fe}_{2} \mathrm{O}_{3}, \mathrm{Cu}_{2} \mathrm{O}$ and $\mathrm{Fe}_{2} \mathrm{O}_{3} / \mathrm{Cu}_{2} \mathrm{O}=0.75 \mathrm{gl}^{-1}$ and irradiation time $=$ $120 \mathrm{~min})$ in the presence of scavengers $(2 \mathrm{mM}$ for $200 \mathrm{ml}$ of respective dye solution) such as $t-\mathrm{BuOH}$ for $\cdot \mathrm{OH},{ }^{58}$ benzoquinone (BQ) for $\mathrm{O}^{2 \cdot},{ }^{59}$ and potassium iodide (KI) for holes and $\cdot \mathrm{OH}^{60}$ The effect of $t$-BuOH, BQ and KI on the photo-removal percentage of RB and JG is shown in (Fig. 6). It was clearly observed that the photo removal percentage of RB was reduced to $35.79 \%, 39.78 \%, 43.11 \%$ and $91.25 \%$ after the addition of KI, $t$ - $\mathrm{BuOH}, \mathrm{BQ}$ and blank, respectively. Then again, the Janus green (JG) is as follows: $t$-BuOH- $43.65 \%$, BQ- $44.78 \%$, KI- $38.65 \%$, and blank-89.14\%. The photocatalytic activity of the nanomaterial surprisingly concealed the scavenge ring effect, indicating that both $\mathrm{O}^{2 \cdot}$ and the $\cdot \mathrm{OH}$ are actively implicated in the photo-removal process.

\subsection{Determination of the antibacterial activity of $\mathrm{Cu}_{2} \mathrm{O}$, $\mathrm{Fe}_{2} \mathrm{O}_{3}$ and the $\mathrm{Fe}_{2} \mathrm{O}_{3} / \mathrm{Cu}_{2} \mathrm{O}$ photocatalyst nanocomposite}

$\mathrm{Cu}_{2} \mathrm{O}, \mathrm{Fe}_{2} \mathrm{O}_{3}$ and the $\mathrm{Fe}_{2} \mathrm{O}_{3} / \mathrm{Cu}_{2} \mathrm{O}$ were further tested for their potential to inhibit test bacterial pathogens by the disc diffusion method (Fig. 15). The result of antibacterial activity showed that there exists a significant zone of inhibition against test pathogens (Table 3). It should be noted that, among the test samples, due to its large surface area, $\mathrm{Fe}_{2} \mathrm{O}_{3} / \mathrm{Cu}_{2} \mathrm{O}$ composites respectively yields the maximum inhibition zones of 20.13, 21.09, 08.23 and 20.60 for Staph. aureus, P. aeruginosa, B. subtilis and E. coli. In the case of $B$. subtilis, whilst only a slight response to $\mathrm{Fe}_{2} \mathrm{O}_{3} / \mathrm{Cu}_{2} \mathrm{O}$ nanocomposite is observed, we have not observed any zone of inhibition in SDW (Sterile Distilled Water) diffused discs against test pathogens. This study clearly suggests that the $\mathrm{Fe}_{2} \mathrm{O}_{3} / \mathrm{Cu}_{2} \mathrm{O}$ nanocomposite inhibits bacterial pathogens by rupturing the outer and inner walls of the cell, which leads to disorganization and leakage of the cell membrane (Fig. 16).

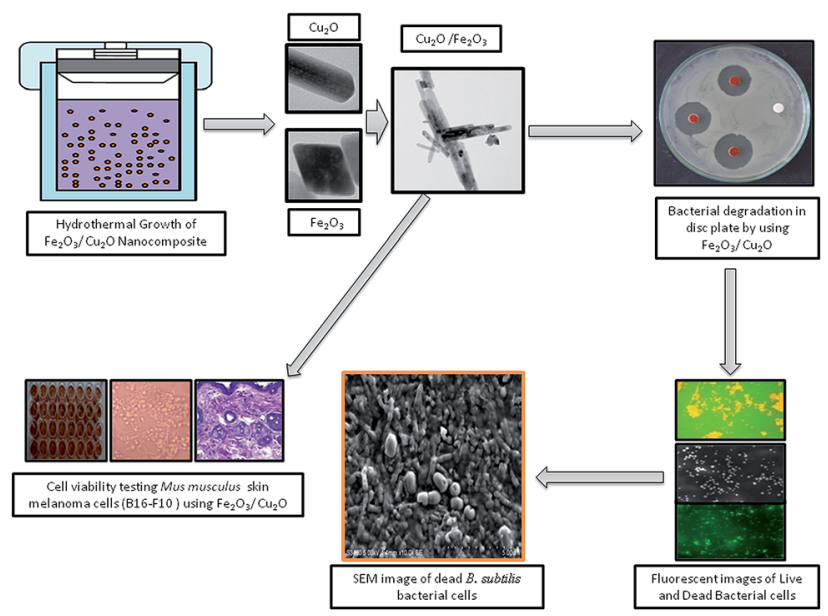

Fig. 14 Hydrothermal growth of the $\mathrm{Fe}_{2} \mathrm{O}_{3} / \mathrm{Cu}_{2} \mathrm{O}$ nanocomposites and the bacterial degradation and cell viability testing studies.

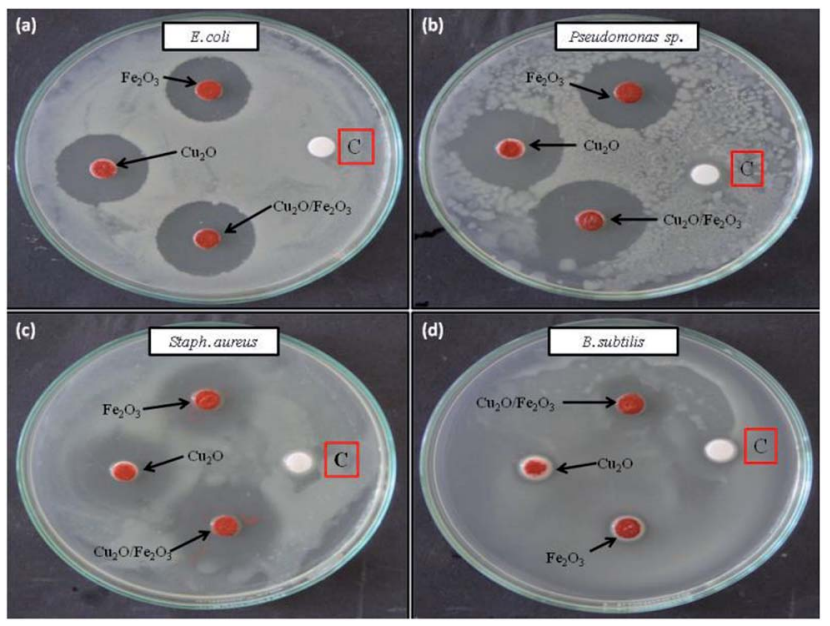

Fig. 15 Antibacterial activity of different $\mathrm{Fe}_{2} \mathrm{O}_{3}, \mathrm{Cu}_{2} \mathrm{O}$ and $\mathrm{Fe}_{2} \mathrm{O}_{3} / \mathrm{Cu}_{2} \mathrm{O}$ nano-composites (a) E. coli; (b) P. aeruginosa; (c) Staph. aureus; (d) $B$. subtilis; [C] sterile distilled water.

\subsection{Probable photocatalytic mechanism with $\mathrm{Fe}_{2} \mathrm{O}_{3} / \mathrm{Cu}_{2} \mathrm{O}$ as the photocatalyst}

This section clearly explains how the movement of the photoinduced charge carriers occurring between $\mathrm{Fe}_{2} \mathrm{O}_{3}$ and $\mathrm{Cu}_{2} \mathrm{O}$ have been systematically estimated using Mullikenelectronegativity theory. ${ }^{61}$ This theory helps explain how a p-n heterojunction functions, according to Anderson's model. ${ }^{62,63}$ The Mulliken-electronegativity of the semiconductor, $E_{\mathrm{CB}}$ and $E_{\mathrm{VB}}$, are respectively the conduction and valence band edge potential, where the band gap of the semiconductor $E_{\mathrm{g}}$ and $E_{\mathrm{e}}$ is the free energy of electrons on the $\mathrm{H}_{2}(4.5 \mathrm{eV})$, for $\mathrm{Cu}_{2} \mathrm{O}$ and

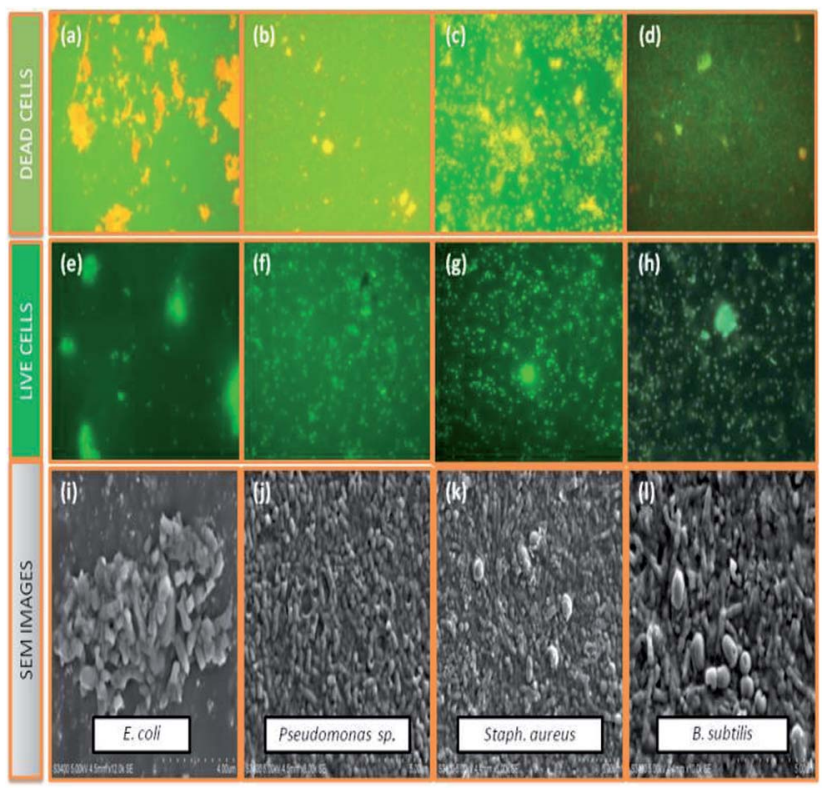

Fig. 16 Selected live and dead cell representative fluorescent microscopic images $(40 \mathrm{X})$ and scanning electron microscopic images of dead cells, (a, e and i) E. coli, $\mathrm{Fe}_{2} \mathrm{O}_{3}$; (b, f and j) Pseudomonas sp., $\mathrm{Cu}_{2} \mathrm{O}$; (c, g and k) Staph. aureus, $\mathrm{Fe}_{2} \mathrm{O}_{3} / \mathrm{Cu}_{2} \mathrm{O}$; (d, h and i) B. subtilis, $\mathrm{Fe}_{2} \mathrm{O}_{3}$ ) $\mathrm{Cu}_{2} \mathrm{O}$ in-general both of the series; green dots represent live bacterial cells, and yellow/orange dots represent dead cells. 
$\mathrm{Fe}_{2} \mathrm{O}_{3}$. The electronegativity values were reported to be 5.32 and $5.88 \mathrm{eV}$, respectively. The probable band gap values of $\mathrm{Cu}_{2} \mathrm{O}$ and $\mathrm{Fe}_{2} \mathrm{O}_{3}$ from the UV-Vis spectrum determine the diffuse reflectance. The conduction and the valence band edges of the $\mathrm{Fe}_{2} \mathrm{O}_{3} /$ $\mathrm{Cu}_{2} \mathrm{O}$ photocatalyst are given in Table 2. Both the conduction band edge of $\mathrm{Cu}_{2} \mathrm{O}$ and $\mathrm{Fe}_{2} \mathrm{O}_{3}$ are respectively negative and positive with respect to the hydrogen reduction potential on the normalized hydrogen scale (Fig. 17). Likewise, the valence band edge of $\mathrm{Fe}_{2} \mathrm{O}_{3}$ is more positive than that of $\mathrm{Cu}_{2} \mathrm{O}$. Both semiconductors with different electronegativities and bands positions in an internal electric field at either side of the junction will build up, being directed from the $\mathrm{Fe}_{2} \mathrm{O}_{3}$ surface to the $\mathrm{Cu}_{2} \mathrm{O}$ surface and become exposed to visible spectrum (400 nm). The photo-generated electrons will, under the influence of an inner electric field, shift from p-type $\mathrm{Cu}_{2} \mathrm{O}$ to n-type $\mathrm{Fe}_{2} \mathrm{O}_{3}$, and the photo-created holes force to transfer from the valence bands of $\mathrm{Fe}_{2} \mathrm{O}_{3}$ to the valence band of $\mathrm{Cu}_{2} \mathrm{O}$. These processes in effect separate and mobilize the photo-generated electron and holes, thereby enhancing the photocatalytic activity of the $\mathrm{Fe}_{2} \mathrm{O}_{3} / \mathrm{Cu}_{2} \mathrm{O}$ photocatalysts.

\subsection{Photo-removal mechanism of dyes}

Hydrogen generation from photo-induced water break-down is increasingly seen as a feasible choice to concurrently solve energy and environmental problems. Various photo-induced $\mathrm{H}_{2}$ generation techniques and photocatalytic water splitting was demonstrated in the visible light spectrum. ${ }^{64-68}$ The low cost and high sustainability features of the reaction system in the photo-removal mechanism of dyes are explained in S1 in ESI. $\dagger$

Electron-hole pairs in the excited $\mathrm{Fe}_{2} \mathrm{O}_{3}$ could be efficiently separated to facilitate an efficient shift into photo-induced electrons between $\mathrm{Fe}_{2} \mathrm{O}_{3}$ and $\mathrm{Cu}_{2} \mathrm{O}$. This radical splitting process makes a crucial task in the removal of dyes. The effectiveness of the

Table 2 The electronegativity, band gap, conduction band (CB) edge and valence band (VB) edge potential of the catalysts on a normalized hydrogen scale

\begin{tabular}{lllll}
$\begin{array}{l}\text { Semiconductor } \\
\text { catalyst }\end{array}$ & $x(\mathrm{eV})$ & $E_{\mathrm{g}}(\mathrm{eV})$ & $E_{\mathrm{CB}}(\mathrm{eV})$ & $E_{\mathrm{VB}}(\mathrm{eV})$ \\
\hline $\mathrm{Fe}_{2} \mathrm{O}_{3}$ & 5.88 & 1.96 & -0.12 & 2.355 \\
$\mathrm{Cu}_{2} \mathrm{O}$ & 5.32 & 1.88 & 0.395 & 1.76
\end{tabular}

Table 3 Antibacterial activity of the $\mathrm{Fe}_{2} \mathrm{O}_{3} / \mathrm{Cu}_{2} \mathrm{O}$ nano-composite against test pathogens ${ }^{a}$

\begin{tabular}{lllll}
\hline \multicolumn{5}{c}{ Zone of inhibition (in mm) } \\
\cline { 2 - 5 } Test sample & B. subtilis & Staph. aureus & P. aeruginosa & E. coli \\
\hline $\mathrm{Fe}_{2} \mathrm{O}_{3}$ & $04.53 \pm 0.11$ & $15.21 \pm 0.33$ & $17.24 \pm 0.12$ & $17.41 \pm 0.06$ \\
$\mathrm{Cu}_{2} \mathrm{O}$ & $02.22 \pm 0.24$ & $16.24 \pm 0.33$ & $17.10 \pm 0.23$ & $18.17 \pm 0.07$ \\
$\mathrm{Fe}_{2} \mathrm{O}_{3} / \mathrm{Cu}_{2} \mathrm{O}$ & $08.23 \pm 0.14$ & $20.13 \pm 0.11$ & $21.09 \pm 0.32$ & $20.60 \pm 0.11$ \\
$\mathrm{Std} . \mathrm{DW}$ & $00.00 \pm 0.00$ & $00.00 \pm 0.00$ & $00.00 \pm 0.00$ & $00.00 \pm 0.00$ \\
$\begin{array}{l}{ }^{a} \text { Values are means of three independent replicates; } \pm \text { indicate standard } \\
\text { error. }\end{array}$
\end{tabular}

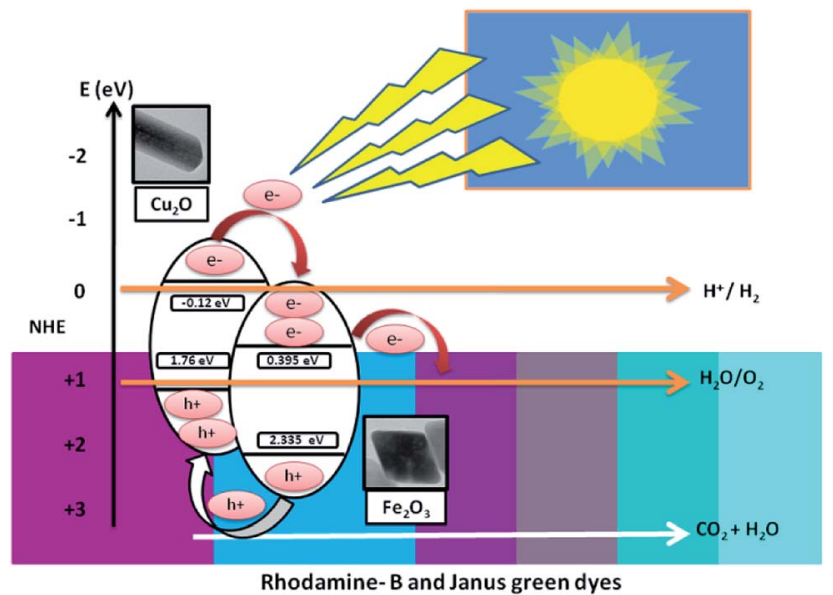

Fig. 17 Projected photocatalytic removal mechanism under visible light irradiation.

photo-reaction very much depends on the efficiency of the adsorption of untreated organic contaminants on the photocatalysts and the process of splitting photo-created electron-hole pairs. The holes can either react or be adsorbed through surface hydroxyl to form hydroxyl radicals. As a result, the adsorption equilibrium was destroyed, permitting dye molecules to move from single elucidation to the interface and to consequently decompose into $\mathrm{CO}_{2}, \mathrm{H}_{2} \mathrm{O}$ and other raw materials through redox reactions.

\subsection{Re-usability of photocatalysts}

The sustainability of a photocatalyst is the most important concern for the booming industry. In order to investigate the stability and durability of $\mathrm{Fe}_{2} \mathrm{O}_{3} / \mathrm{Cu}_{2} \mathrm{O}$, nanomaterial recycling experiments were conducted for the photo-removal of $\mathrm{RB}$ and JG. After the completion of each cycle, the photocatalyst was collected using an external magnet, washed with double
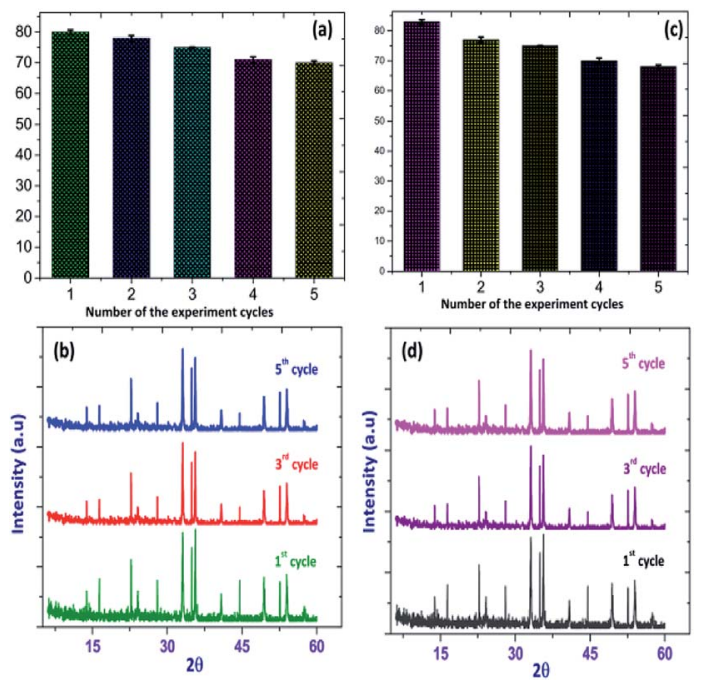

Fig. 18 Recycling performance of the photo-removal of (a) Rhodamine- $B(R B)(b)$ Janus green (JG), and XRD patterns of (c) Rhodamine$\mathrm{B}(\mathrm{RB}): \mathrm{Fe}_{2} \mathrm{O}_{3} / \mathrm{Cu}_{2} \mathrm{O}$ (d) Janus green (JG): $\mathrm{Fe}_{2} \mathrm{O}_{3} / \mathrm{Cu}_{2} \mathrm{O}$ before and after successful cycles of recycling. 
distilled water, dried overnight, and reused. ${ }^{66,67}$ The photoremoval percentages of $\mathrm{RB}$ and JG for five successive cycles were found to be $79.15 \%, 74.65 \%, 75.45 \%, 74.98 \%$ and $73.24 \%$, respectively, and are shown in Fig. 18.

The $\mathrm{Fe}_{2} \mathrm{O}_{3} / \mathrm{Cu}_{2} \mathrm{O}$ nanomaterial exhibits an average of $76.24 \%$ for photocatalytic activity after five successive cycles. The reduction in activity after two cycles is due to the loss of catalyst during the washing process. ${ }^{69}$ In addition, there is no obvious change observed in the XRD pattern of $\mathrm{Fe}_{2} \mathrm{O}_{3}$ in (Fig. 18) after five cycles. These results indicated that the $\mathrm{Fe}_{2} \mathrm{O}_{3} / \mathrm{Cu}_{2} \mathrm{O}$ materials could be used as a stable photo-catalyst for the removal of organic pollutants in the form of dyes in industrial wastewater.

\subsection{Toxicity tests of $\mathrm{Fe}_{2} \mathrm{O}_{3}, \mathrm{Cu}_{2} \mathrm{O}$ and $\mathrm{Fe}_{2} \mathrm{O}_{3} / \mathrm{Cu}_{2} \mathrm{O}$}

To further illustrate the bio-compatible advantage of the proposed photocatalyst, up-conversion materials for emitting visible light were used as candidates for both in vivo and in vitro bio-imaging as well as in photodynamic therapy. We measured the toxicity of $\mathrm{Fe}_{2} \mathrm{O}_{3}, \mathrm{Cu}_{2} \mathrm{O}$ and $\mathrm{Fe}_{2} \mathrm{O}_{3} / \mathrm{Cu}_{2} \mathrm{O}$ using Musmusculus skin melanoma cells of various concentrations $\left(5-500 \mathrm{~g} \mathrm{ml}^{-1}\right)$. The results suggested that the viability of (B16-F10) cells decreased in a dose-dependent manner in each sample (Fig. 19), clearly showing that, at a $5 \mathrm{~g} \mathrm{ml}^{-1}$
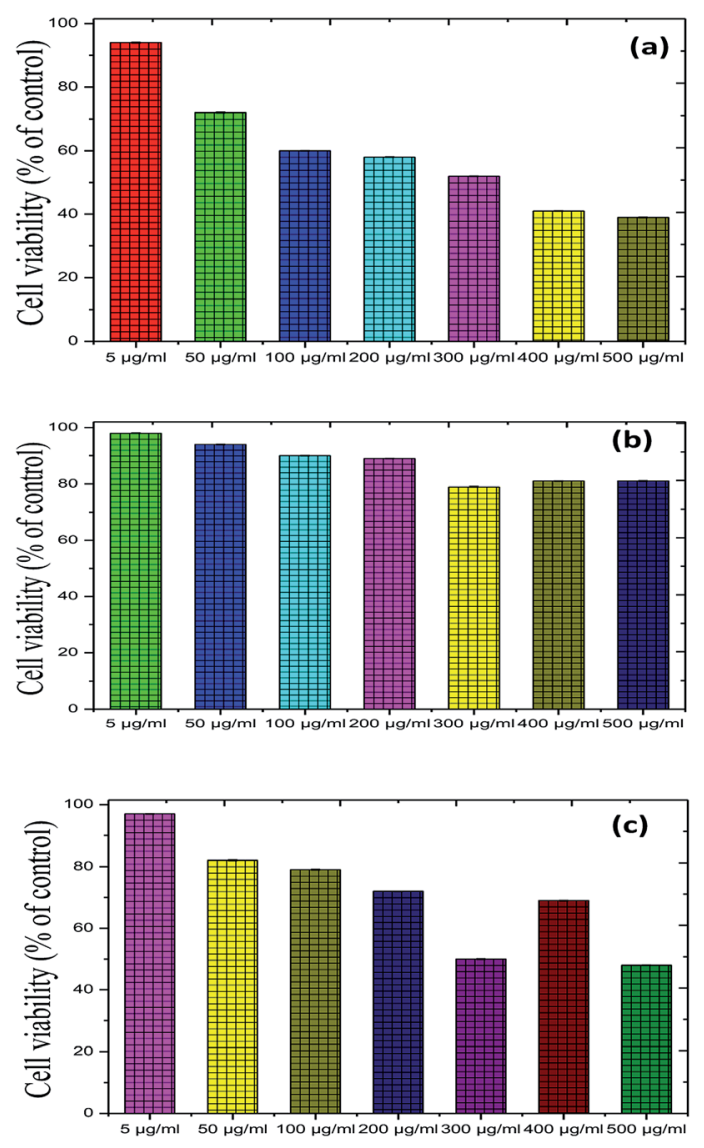

Fig. 19 Recycling performance of the photo-removal of (a) Rhodamine- $B(R B)(b)$ Janus green (JG), and XRD patterns of (c) Rhodamine$\mathrm{B}(\mathrm{RB}): \mathrm{Fe}_{2} \mathrm{O}_{3} / \mathrm{Cu}_{2} \mathrm{O}$ (d) Janus green (JG): $\mathrm{Fe}_{2} \mathrm{O}_{3} / \mathrm{Cu}_{2} \mathrm{O}$ before and after successful cycles of recycling. concentration, the lowest concentration of the three respective samples used in the assay did not reduce the cell viability noticeably as compared to other increased concentrations, among which $\mathrm{Fe}_{2} \mathrm{O}_{3} / \mathrm{Cu}_{2} \mathrm{O}$ was found to be low in a systematic manner. Therefore, $\mathrm{Fe}_{2} \mathrm{O}_{3} / \mathrm{Cu}_{2} \mathrm{O}$ is the safest and the superlative alternative in terms of toxicity in biological application.

\section{Conclusions}

In this experimental work, a unique and visible light-driven $\mathrm{Fe}_{2} \mathrm{O}_{3} / \mathrm{Cu}_{2} \mathrm{O}$ composite photo-catalyst was prepared by a simple, eco-friendly and cost-effective hydrothermal method for multi-purpose application. Rhodamine-B (RB) and Janus green (JG) could be easily decolorized by $\mathrm{Fe}_{2} \mathrm{O}_{3} / \mathrm{Cu}_{2} \mathrm{O}$ under visible light irradiation. Furthermore, the photocatalyst was recycled several times without any observable loss of photocatalytic activity, making it suitable for use in dye removal in wastewater. Moreover, the synthesized materials were found to be highly stable in the photocatalytic process; displayed antibacterial properties against E. coli, P. aeruginosa, Staph. aureus and B. subtilis; and anti-cancer properties against Musmusculus skin melanoma cells (B16-F10). These results suggest that these composite materials can be utilized in the biomedical field and for catalysis and energy conversion systems.

\section{Conflicts of interest}

The authors declare no competing financial interests.

\section{Acknowledgements}

One of the author M. R. Abhilash (IF160104) thanks the Department of Science and Technology, Govt. of India, for awarding financial assistance through the DST - INSPIRE Fellowship to carry out the research work.

\section{Notes and references}

1 J. Ke, M. A. Younis, Y. Kong, H. Zhou, J. Liu, L. Lei and Y. J. N.-m. I. Hou, Nano-Micro Lett., 2018, 10, 69.

2 E. Serrano, G. Rus and J. Garcia-Martinez, Renewable Sustainable Energy Rev., 2009, 13, 2373-2384.

3 P. Verma, Y. Kuwahara, K. Mori and H. Yamashita, J. Mater. Chem. A, 2016, 4, 10142-10150.

4 P. V. Kamat, J. Phys. Chem. C, 2007, 111, 2834-2860.

5 B. Neppolian, Q. Wang, H. Yamashita and H. Choi, Appl. Catal., A, 2007, 333, 264-271.

6 D. D. Ramos, P. C. S. Bezerra, F. H. Quina, R. F. Dantas, G. A. Casagrande, S. C. Oliveira, M. R. S. Oliveira, L. C. S. Oliveira, V. S. Ferreira, S. L. Oliveira and A. Machulek, Environ. Sci. Pollut. Res., 2015, 22, 774-783.

7 J. Z. Bloh, R. Dillert and D. W. Bahnemann, Environ. Sci. Pollut. Res., 2012, 19, 3688-3695.

8 C. Cheng, A. Amini, C. Zhu, Z. L. Xu, H. S. Song and N. Wang, Sci. Rep., 2014, 4, 1-5. 
9 C. Cheng, M. Lei, L. Feng, T. L. Wong, K. M. Ho, K. K. Fung, M. M. T. Loy, D. P. Yu and N. Wang, ACS Nano, 2009, 3, 5358.

10 C. Cheng, T. L. Wang, L. Feng, W. Li, K. M. Ho, M. M. T. Loy, K. K. Fung and N. Wang, Nanotechnology, 2010, 21, 1-5.

11 C. Z. Yuan, H. B. Wu, Y. Xie and X. W. Lou, Angew. Chem., Int. Ed., 2014, 53, 1488-1504.

12 B. Neppolian, H. Yamashita, Y. Okada, H. Nishijima and M. Anpo, Catal. Lett., 2005, 105, 111-117.

13 G. Thennarasu, S. Kavithaa and A. Sivasamy, Environ. Sci. Pollut. Res., 2012, 19, 2755-2765.

14 H. Seema, K. C. Kemp, V. Chandra and K. S. Kim, Nanotechnology, 2012, 23, 1-8.

15 Q. Y. Tian, W. Wu, L. L. Sun, S. L. Yang, M. Lei, J. Zhou, Y. Liu, X. H. Xiao, F. Ren, C. Z. Jiang and V. A. L. Roy, ACS Appl. Mater. Interfaces, 2014, 6, 13088-13097.

16 Y. Ma, X. Zhu, S. Xu, G. He, L. Yao, N. Hu, Y. Su, J. Feng, Y. Zhang and Z. J. A. C. B. E. Yang, Appl. Catal., B, 2018, 234, 26-36.

17 S. G. Babu, R. Vinoth, P. S. Narayana, D. Bahnemann and B. Neppolian, APL Mater., 2015, 3, 1-8.

18 Y. Xu and M. A. A. Schoonen, Am. Mineral., 2000, 85, 543556.

19 S. Zhang, Z. Lin, L. Ji, Y. Li, G. Xu, L. Xue, S. Li, Y. Lu, O. Toprakci and X. Zhang, J. Mater. Chem., 2012, 22, 14661-14666.

20 N. X. Li, M. C. Liu, Z. H. Zhou, J. C. Zhou, Y. M. Sun and L. J. Guo, Nanoscale, 2014, 6, 9695-9702.

21 J. S. Jiang, L. Gao, X. L. Yang and J. K. Guo, Acta Phys.-Chim. Sin., 2000, 16, 312-316.

22 X. Zhang, Y. G. Niu, X. D. Meng, Y. Li and J. P. Zhao, CrystEngComm, 2013, 15, 8166-8172.

23 T. K. Townsend, E. M. Sabio, N. D. Browning and F. E. Osterloh, Energy Environ. Sci., 2011, 4, 4270-4275.

24 G. S. McCarty, J. Appl. Phys., 2006, 99, 1-11.

25 N. J. Cherepy, D. B. Liston, J. A. Lovejoy, H. M. Deng and J. Z. Zhang, J. Phys. Chem. B, 1998, 102, 770-776.

26 I. Mamonova, I. Babushkina, I. Norkin, E. Gladkova, M. Matasov and D. J. N. i. R. Puchin'yan, Nanotechnol. Russ., 2015, 10, 128-134.

27 A. Azam, A. S. Ahmed, M. Oves, M. S. Khan, S. S. Habib and A. Memic, Int. J. Nanomed., 2012, 7, 6003.

28 M. Xu, D. Fujita, S. Kajiwara, T. Minowa, X. Li, T. Takemura, H. Iwai and N. J. B. Hanagata, Biomaterials., 2010, 31, 80228031.

29 Á. Dávila-Grana, L. Diego-González, Á. González-Fernández and R. J. I. j. o. m. s. Simón-Vázquez, Int. J. Mol. Sci., 2018, 19, 246.

30 M. A. Maurer-Jones, Y.-S. Lin and C. L. J. A. n. Haynes, ACS Nano, 2010, 4, 3363-3373.

31 H. A. Jeng and J. Swanson, J. Environ. Sci. Health, Part A: Toxic/Hazard. Subst. Environ. Eng., 2006, 41, 2699-2711.

32 R. J. N. T. Brayner, Nano Today, 2008, 3, 48-55.

33 X. Chen, X. Q. Huang, C. P. Zheng, Y. N. Liu, T. Y. Xu and J. Liu, J. Mater. Chem. B, 2015, 3, 7020-7029.
34 R. Augustine, H. N. Malik, D. K. Singhal, A. Mukherjee, D. Malakar, N. Kalarikkal and S. Thomas, J. Polym. Res., 2014, 21, 1-17.

35 Y. H. Zhang, N. Zhang, Z. R. Tang and Y. J. Xu, ACS Nano, 2012, 6, 9777-9789.

36 S. Thangavel, S. Thangavel, N. Raghavan, R. Alagu and G. Venugopal, J. Phys. Chem. Solids, 2017, 110, 266-273.

37 Q. Hua, D. L. Shang, W. H. Zhang, K. Chen, S. J. Chang, Y. S. Ma, Z. Q. Jiang, J. L. Yang and W. X. Huang, Langmuir, 2011, 27, 665-671.

38 K. Sivula, R. Zboril, F. Le Formal, R. Robert, A. Weidenkaff, J. Tucek, J. Frydrych and M. Gratzel, J. Am. Chem. Soc., 2010, 132, 7436-7444.

39 B. De, B. Voit and N. Karak, RSC Adv., 2014, 4, 58453-58459. 40 Q. Hua, T. Cao, H. Z. Bao, Z. Q. Jiang and W. X. Huang, Chemsuschem, 2013, 6, 1966-1972.

41 Y. K. Hsu, C. H. Yu, Y. C. Chen and Y. G. Lin, $R S C A d v ., 2012$, 2, 12455-12459.

42 C. Hao, F. Feng, X. H. Wang, M. Zhou, Y. T. Zhao, C. W. Ge and K. Wang, RSC Adv., 2015, 5, 21161-21169.

43 B. Lu, A. Liu, H. Wu, Q. Shen, T. Zhao and J. J. L. Wang, Langmuir, 2016, 32, 3085-3094.

44 S. G. Ghugal, S. S. Umare and R. J. R. A. Sasikala, RSC Adv., 2015, 5, 63393-63400.

45 M. Sahu and P. Biswas, Nanoscale Res. Lett., 2011, 6, 1-14.

46 D. K. Surendran, M. M. Xavier, V. P. Viswanathan and S. Mathew, Environ. Sci. Pollut. Res., 2017, 24, 15360-15368.

47 A. Guedes, J. M. F. Ferreira and A. C. Ferro, Ceram. Int., 2009, 35, 1939-1945.

48 B. D. Viezbicke, S. Patel, B. E. Davis and D. P. Birnie, Phys. Status Solidi B, 2015, 252, 1700-1710.

49 N. Nilius, H. Fedderwitz, B. Gross, C. Noguera and J. Goniakowski, Phys. Chem. Chem. Phys., 2016, 18, 67296733.

50 R. H. Goncalves, B. H. R. Lima and E. R. Leite, J. Am. Chem. Soc., 2011, 133, 6012-6019.

51 W. N. A. Guerra, J. M. T. Santos and L. R. R. J. W. S. de Araujo, Water Sci. Technol., 2012, 66, 158-164.

52 A. Gómez, A. Torres-Arenas, J. Vergara-Sánchez, C. Torres, P. Reyes, H. Martínez and H. J. A. A. Saldarriaga-Noreña, AIP Adv., 2017, 7, 105304.

53 W. Anku, S. O.-B. Oppong, S. K. Shukla and P. P. J. A. C. S. Govender, Acta Chim. Slov., 2016, 63, 380-391. 54 Y.-f. Fang, Y.-p. Huang, D.-f. Liu, Y. Huang, G. Wei and J. J. J. o. E. S. David, J. Environ. Sci., 2007, 19, 97-102.

$55 \mathrm{~K} . \mathrm{Yu}, \mathrm{S}$. Yang, H. He, C. Sun, C. Gu and Y. J. T. J. o. P. C. A. Ju, J. Phys. Chem. A, 2009, 113, 1002410032.

56 S. Xia, L. Zhang, G. Pan, P. Qian and Z. J. P. C. C. P. Ni, Phys. Chem. Chem. Phys., 2015, 17, 5345-5351.

57 J. Kashyap, S. M. Ashraf and U. J. A. O. Riaz, ACS Omega, 2017, 2, 8354-8365.

58 M. C. Yin, Z. S. Li, J. H. Kou and Z. G. Zou, Environ. Sci. Technol., 2009, 43, 8361-8366.

59 M. R. Sohrabi and M. Ghavami, J. Hazard. Mater., 2008, 153, 1235-1239. 
60 X. Van Doorslaer, P. M. Heynderickx, K. Demeestere, K. Debevere, H. Van Langenhove and J. Dewulf, Appl. Catal., B, 2012, 111, 150-156.

61 J. P. Perdew, R. G. Parr, M. Levy and J. L. Balduz, Phys. Rev. Lett., 1982, 49, 1691-1694.

62 S. K. Lakhera, A. Watts, H. Y. Hafeez and B. Neppolian, Catal. Today, 2018, 300, 58-70.

63 L. S. Li and X. Yan, J. Phys. Chem. Lett., 2010, 1, 2572-2576.

64 L. C. Olsen, F. W. Addis and W. Miller, Sol. Cells, 1982, 7, 247-279.
65 Y. F. Sun, H. Cheng, S. Gao, Z. H. Sun, Q. H. Liu, Q. Liu, F. C. Lei, T. Yao, J. F. He, S. Q. Wei and Y. Xie, Angew. Chem., Int. Ed., 2012, 51, 8727-8731.

66 B. Seger, A. B. Laursen, P. C. K. Vesborg, T. Pedersen, O. Hansen, S. Dahl and I. Chorkendorff, Angew. Chem., Int. Ed., 2012, 51, 9128-9131.

67 Z. D. Meng, L. Zhu, J. G. Choi, C. Y. Park and W. C. Oh, Nanoscale Res. Lett., 2011, 6, 165-173.

68 Q. J. Xiang, J. G. Yu and M. Jaroniec, Chem. Soc. Rev., 2012, 41, 782-796.

69 Q. Q. Liang, L. H. Yu, W. Jiang, S. Zhou, S. T. Zhong and W. Jiang, J. Photochem. Photobiol., A, 2017, 335, 165-173. 